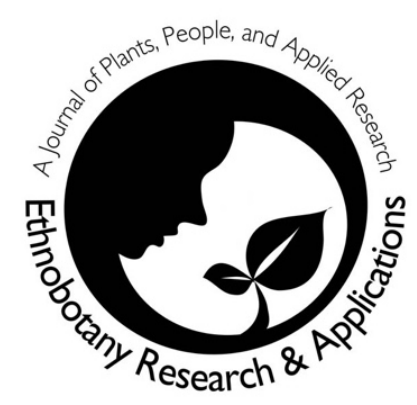

\title{
Quantitative ethnomedicinal study of indigenous medicinal plants used for digestive disorders of Laspur Valley, Chitral, Northern Pakistan
}

\author{
Sher Wali, Hammad Ahmad Jan, Rainer W. Bussmann
}

\section{Research}

\begin{abstract}
Background: The present study was the first one of its own kind conducted in the study area. Throughout the world digestive system diseases and their related symptoms are widely prevalent. People of Chitral still heavily rely upon therapeutic plants to cure digestive disorders.
\end{abstract}

Aim of the study: The present study was conducted in order to document the traditional uses of medicinal plants for the cure of digestive disorders in Laspur Valley of Chitral.

Methods: Ethnomedicinal data was obtained from 200 inhabitants of the area through face to face interviews and semi-structured questionnaires. To analyze data quantitatively, Use-Value (UV), Familiarity-Index (FI), Family Importance Value (FIV), Consensus-Index (Cl), and Informant Consensus Factor indices (ICF) were applied.

Results: A total of 44 medicinal plants were documented. The recurring life forms were herbs $(75 \%)$, shrubs $(15.91 \%)$ and trees $(6.82 \%)$. The most frequently utilized part was the leaves $(43.18 \%)$. To prepare medicine leaves were used unprocessed in fresh/dried form, as powder, and decoction, and were usually taken orally. The FI value was led by Coriandrum sativum (0.285). The family Apiaceae had the maximum FIV value (46.5). The value of "Cl" was highest for Coriandrum sativum. ICF values for Dysentery, Vomiting and Intestinal Disorders (1.0) presented the maximum consensus factor.

Conclusion: The practice of using therapeutic plants to cure digestive disorders by medicinal plants is still prevalent in the study area.
Key words: Quantitative ethnomedicinal; indigenous medicinal plants; digestive disorders; Laspur valley; Northern Pakistan

Correspondence
Sher Wali', Hammad Ahmad Jan*1, Rainer W.
Bussmann²
1Department of Botany, Islamia College Peshawar,
Pakistan
'Department of Etnnobotany, Institute of Botany, llia
State University, Tbilisi, Georgia
*Corresponding author: hajmughul@yahoo.com
Ethnobotany Research \& Applications
18:32 (2019)

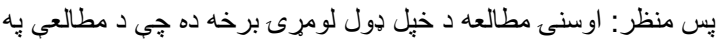

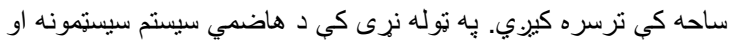

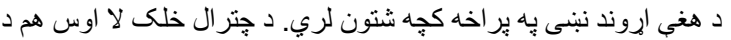

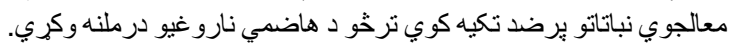

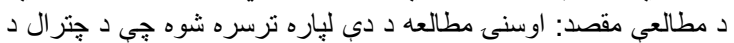

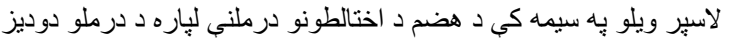
كارول مستند كري.

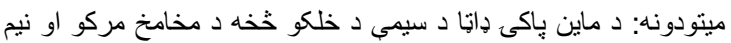

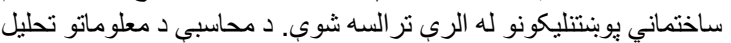

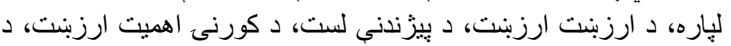

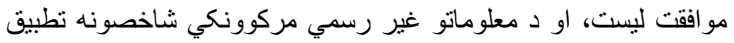
شوي.

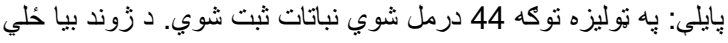

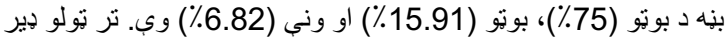

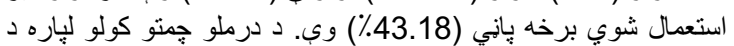




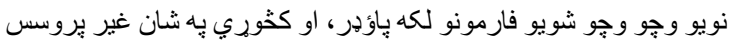

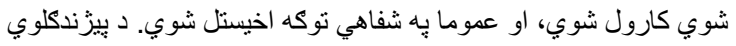

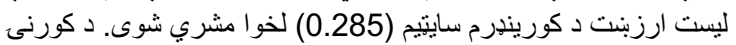

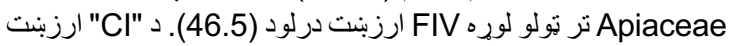

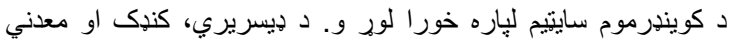

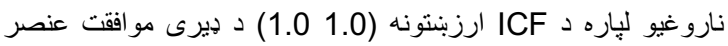

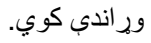

\section{Background}

For basic healthcare, almost $80 \%$ of the human population depends upon therapeutic plants (WHO, 2002; Sarma et al. 2012). Plant based remedies are also popular in the West, because they are assumed to have negligible or no negative effects if directed appropriately (Jordan et al. 2010). Other than therapeutic use, plants are progressively utilized as a part of beauty care products and nutraceuticals (Rokaya et al. 2014).

Natural remedies were found to be often a viable option to treat an extensive variety of illnesses (Rokaya et al. 2014), including digestive ailments (Heinrich et al. 1992; Manandhar, 2002; Rokaya et al. 2014; Street and Prinsloo, 2013). Individuals living in the mountainous regions of Pakistan utilize plants for numerous reasons, for example, as medicines, protection, timber, firewood, kindling, sustenance and feed, housing, etc. (Hussain et al. 1996). Throughout the world Digestive diseases and their related symptoms are very widespread. Nearly $8-10 \%$ of the population is affected even in the developed world. The primary reasons are poverty, changes in dietary patterns, and water pollution, among others (Mc Michael 2006; Molares and Ladio, 2009).

The utilization of therapeutic plants for disorders of digestive system is common. Strikingly, a characteristic of these plants is their specific odor or flavor: they are typically bitter, fragrant, and also astringent. These organoleptic qualities originate from secondary metabolites, for example, terpenoids and their derivates (Molares and Ladio, 2009), and tannins or other chemical components (Heinrich et al. 1992).

These qualities can be precious memory aids with regards to the cultural transference of this ethnomedicinal data (Molares and Ladio, 2009). Information on plant use is normally transmitted orally, including in Pakistan (Haq, 1983; Khan and Zaidi, 1991; Haq and Hussain, 1993; Hussain et al. 1996; Shinwari and Khan, 2000; Gilani et al. 2001; Ahmad et al. 2009; Qureshi et al. 2009; Abbasi et al. 2013; Rahman et al. 2016). People of Chitral still heavily rely upon therapeutic plants for majority of their illnesses, thus a loss of these plant assets would hamper the current healthcare system in the area. Actions for the protection especially of therapeutic plants of Chitral valley are critically required (Ali and Qaiser, 2009). Because verbally conveyed information is held especially by the older generation, a large portion of it can vanish easily with their passing (Kim et al. 2006; Kim and Song, 2008). The present research aimed at recording the ethnomedicinal practices of therapeutic plants to cure Digestive Disorders (DD) in Laspur Valley, and to assess the use of plant species in light of the literature review. In particular, we tried to answer the following questions: (i) which plant species are used for DDs in Laspur Valley (ii) what DDs are cured with the maximum amount of therapeutic species? (iii) are certain families of plants more or less utilized than anticipated in DDs? and (iv) what types of illnesses are ordinarily cured with the help of which parts of plant, plant species, families and administration modes?

\section{Materials and Methods}

\section{Introduction to the study area}

Laspur valley is one of the most beautiful valleys of Chitral. It is located to the north-east of Chitral town, at a distance of $125 \mathrm{~km}$. The total length of the valley is around $104 \mathrm{~km}, 57 \mathrm{~km}$ of which are above the village of Laspur, representing an uncultivated tract. According to the census 2017 the population is approximately 9500 people distributed in 1450 houses and the literacy rate is more than $65 \%$. Laspur valley lies in between latitude $36^{\circ} 1$ '56.3" N, $72^{\circ} 32^{\prime} 26.8^{\prime \prime} \mathrm{E}$ (Fig. 1). The elevation of Laspur valley is around $2400 \mathrm{~m}$. Temperature hardly exceeds the limit of $30^{\circ} \mathrm{C}$ and the Minimum temperature is $-8^{\circ} \mathrm{C}$. Laspur borders with Gilgit in the north, Mastuj in the south, and high snowy mountains separate it from Swat in the west. Laspur valley harbors six main villages namely Balim, Sor-Laspur, Harchin, Broke, Raman and Gasht. The most beautiful and attractive village among them is Balim. Shandur, the highest polo ground of the world, is only $6 \mathrm{~km}$ away, in the meadow area of Laspur, a flat piece of land situated $3725 \mathrm{~m}$ above sea level. There are 5 colleges, 18 private and 16 government middle and high schools in Laspur valley (www.chitraltoday.net).

\section{Literature review}

Different online data bases (ISI Web of Science, MEDLINE, Science Direct, Scopus, and Google Scholar) were searched using the terms "therapeutic plants", "medicinal plants", "gastrointestinal", "digestive disorders", "diarrhea", "dysentery", "stomach" and "Chitral, Pakistan" before beginning the field work. The term "Chitral, Pakistan" was employed to constrain the topographical extent of the search. The exactness of species names given in this work depend upon that from the original bases. 
But, we confirmed presently recognized name(s) in online classification sources (http://www.theplantlist.org) and

(http://www.tropicos.org/project/Pakistan). Available vernacular names were also recorded. Habitat and origin (wild/developed) of each plant species was documented (Baral and Kurmi, 2006; Rokaya et al. 2014).

To get phytochemical or pharmacological data about respective therapeutic plants species we also used the above stated databases.

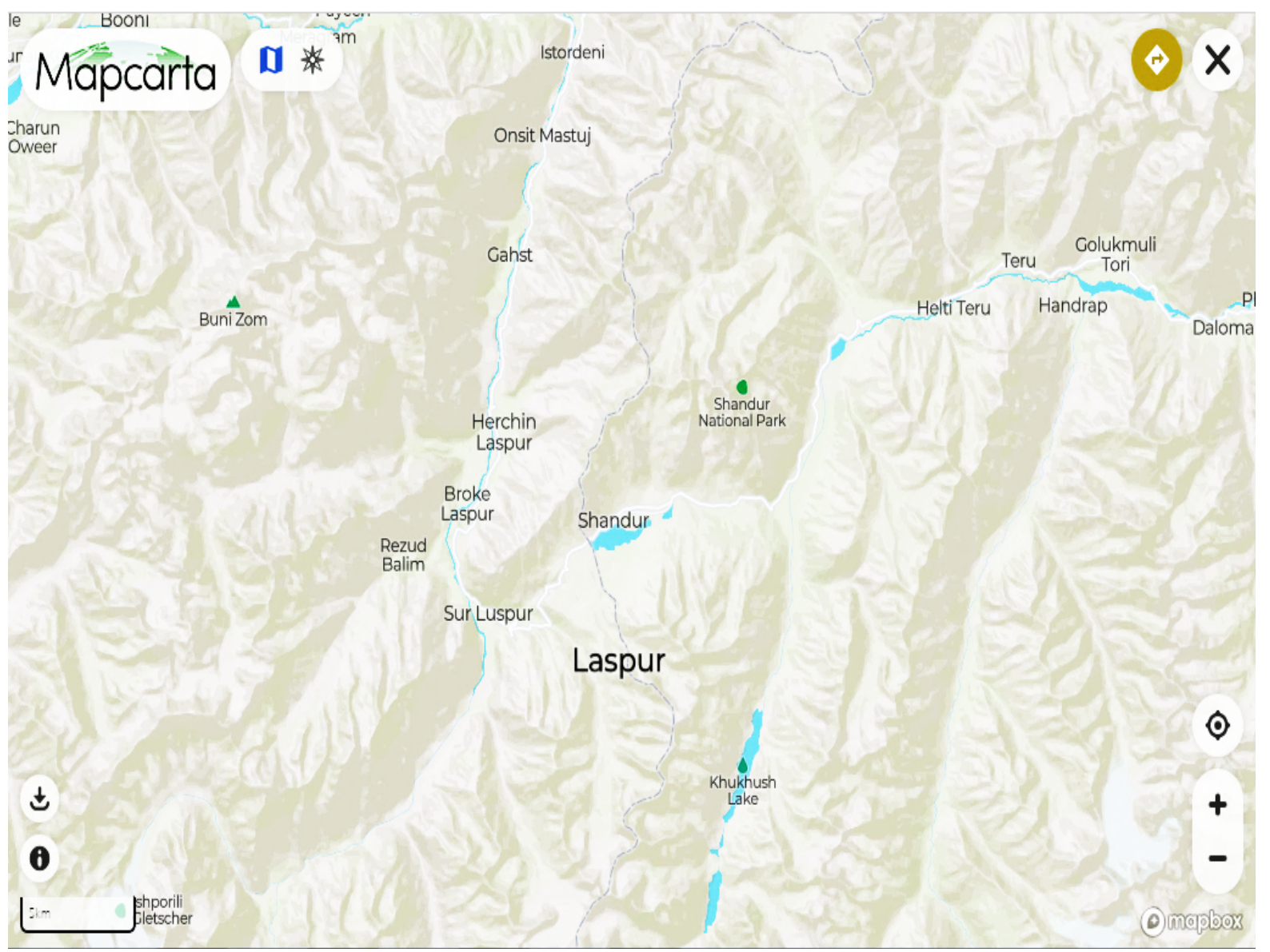

Fig. 1. Map of the study area (www.mapcarta.com)

\section{Collection of ethnomedicinal data}

The ethnomedicinal field survey was completed in 2014-2015 to record the data about therapeutic plants utilized by the local population. Data was gathered through semi-structured interviews (Akerreta et al. 2007). All interviews were conducted after receiving prior informed consent from the participants. Two hundred and eight (200) participants 136 men including 8 herbalists $(68 \%)$ and $64(32 \%)$ women were interviewed. This random sample was $2.105 \%$ of the population of the studied community. They were asked about information on plants utilized against Digestive Disorders (DDs), folk names, plant parts utilized and the preparation mode. All the informants and expert herbalists were chosen randomly, and no appointments were scheduled before the visits.

\section{Plant sampling and identification}

Specimens of plants were collected and identified through standard taxonomic techniques and scientific names were confirmed online through (http://www.tropicos.org/extend/Pakistan and "The Plant List" (http://www.theplantlist.org/). The specimens were submitted to the Herbarium of Department of Botany, Islamia College Peshawar, Pakistan.

\section{Data analysis \\ Quantitative analysis of data}

The ethnomedicinal data gathered was analyzed statistically. The species were assembled into classes of diseases in view of emic data gathered from informants. The aim was to document all the data as it was given by the informants to us. A quantitative investigation was completed with the 
specific goal to assess the significance of those species in the culture of the elderly individuals of the area. This sort of investigation, the first of its kind in this area, has been made using the accompanying indices:

\section{Use Value (UV)}

In order to calculate the relative importance of native medicinally important plant species for DDs Use Value (UV) (Phillips et al. 1994) a quantitative method was applied. UV is calculated as:

$$
U V=\Sigma U i / n
$$

Ui $=$ Total number of used records/species

$\mathrm{n}=$ Sum of respondents questioned for a particular medicinal plant.

\section{Familiarity Index (FI)}

To find out the popularity of therapeutic plant among the folk communities a relative indicator Familiarity Index (FI) was used (Tabuti et al. 2004; Kidane et al. 2014a):

$$
F I=F C / N
$$

$F C=$ Particular species' frequency stated as remedy $\mathrm{N}=$ Sum of informants take part in survey

\section{Family Importance Value (FIV)}

To know the importance and familiarity of a botanical family, the importance value (FIV) was applied (Kayani et al. 2014), using the following formula:

$$
F I V=F C(\text { family }) / N \times 100
$$

$\mathrm{FC}=$ Informants number citing the family $\mathrm{N}=$ Sum of respondents take part in this survey

\section{Informant Consensus Factor (ICF)}

In order to elucidate the agreement between use of plants for different disease groups and informants of the study area the Informant Consensus Factor (FIC) was calculated following (Trotter and Logan, 1986; Heinrich et al. 1998; Kayani et al. 2015; Butt et al. 2015):

$$
I C F=N u r-N t / N u r-1
$$

Nur $=$ Total number of reports of the use category in inquiry

$\mathrm{Nt}=$ Total number of species used in this category

\section{Consensus index $(\mathrm{Cl})$}

To find out the percentage of informants in the area with folk medicinal knowledge of medicinal plant species the Consensus index $(\mathrm{Cl})$ was (Rahman et al. 2016).
Where

$$
C I=n / N \times 100
$$
$\mathrm{n}=$ Number of respondents citing DDs species
$\mathrm{N}=$ Total number of informants

\section{Results and discussion \\ Socio-demographic evidence}

A total of 200 participants were interviewed and the participants' age ranged from $20-80$ years. A total of 136 were men $(68 \%)$ and 64 women $(32 \%)$ (Table 1). The prevalence of men was related to gender issues, i.e. that women cannot talk with male strangers (the interviewer). This certainly had some influence on the outcomes of our work in the form of a barrier in the transfer of knowledge documentation due to which we did not document some precious knowledge of medicinal plants known to women. The vast majority of the participants were farmers or shepherds, still active or retired, with a small number of workers, shopkeepers, Government servants, housewives and some folk herbalists participating. A large portion of the respondents had not finished secondary school (Fig. 2).

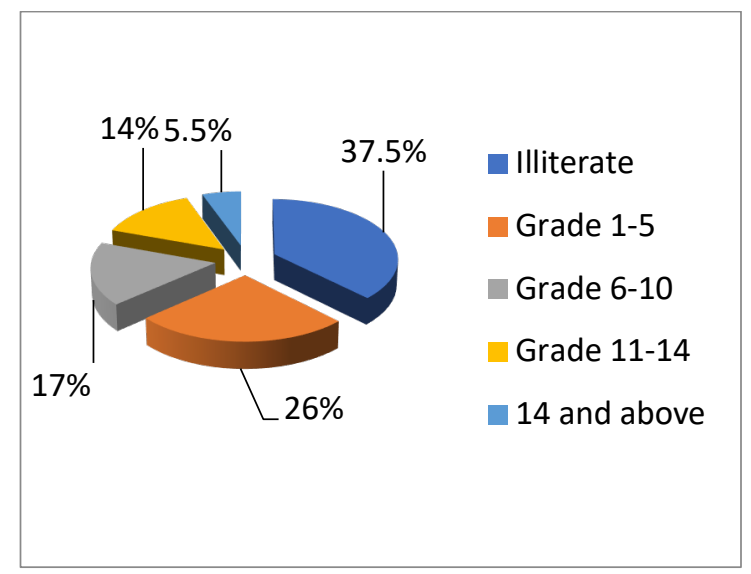

Fig. 2. Percentage of participants on the basis of education

The most noteworthy cite frequency of remedial species utilized for DDs were documented from individuals with age range 50-80 years, while little data was acquired from younger as well as older respondents (Table 1, Fig. 3). In the $1^{\text {st }}$ group (younger respondents), this may be because of progressed and dynamic lack of engagement in the ethics of "folk culture" and "rural advancement". In the $2^{\text {nd }}$ case (older respondents), the lack of information was based on a certain reluctance / objective difficulties in contributing in interviews. Most reports were gotten from the rural groups when contrasted with urban groups, similar to other studies (Giday et al. 2009). 
Table 1. Demographic description of the participants

\begin{tabular}{lll}
\cline { 1 - 1 } Total participants & & Percentage\% \\
\cline { 1 - 1 } Male & 136 & 68 \\
Female & 64 & 32 \\
\cline { 1 - 1 } Age Group & 43 & 21.5 \\
\cline { 1 - 2 } $20-40$ & 84 & 42 \\
$41-60$ & 62 & 31 \\
$61-80$ & 11 & 5.5 \\
81-above & & \\
\cline { 1 - 1 } Education Level & 75 & 37.5 \\
\cline { 1 - 2 } Illiterate & 52 & 26 \\
Grade 1-5 & 34 & 17 \\
Grade 6-10 & 28 & 14 \\
Grade 11-14 & 11 & 5.5 \\
14 and above & & \\
\hline
\end{tabular}

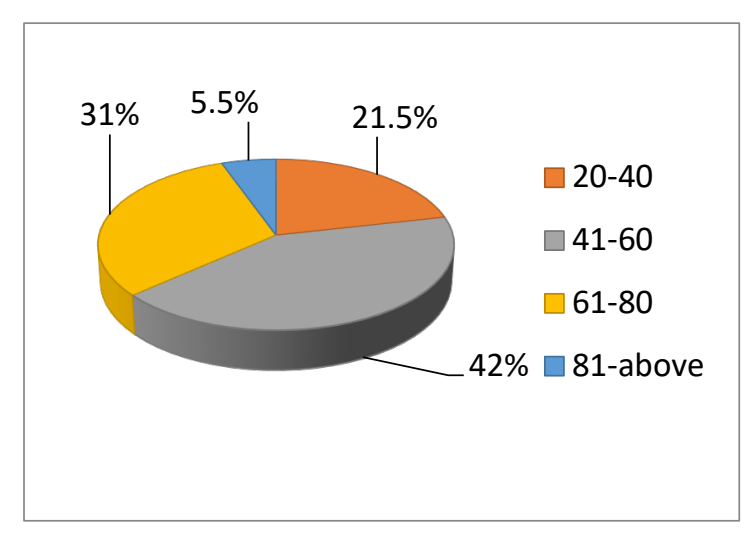

Fig. 3. Age distribution of participants

\section{Diversity of medicinal plants used for DDs}

In study area 44 species used to treat DDs were documented and the therapeutic plant species belonged to 21 families (Table 2). The documented therapeutic plants used for DDs were categorized into twelve different DDs classes (Table 3 and Fig. 4). Stomachic was the ailment cured through the maximum number of medicinal plant species (18), tailed by constipation (6) and laxative (5). In table 3 some important local recipes are listed. These were more commonly used recipes of the area.

Medicinal plants used for DDs presented a diversity of growth forms (Fig. 5). Herbs were most common $(75 \%)$, followed by shrubs $(15.91 \%)$, and trees (6.82\%), similar to other studies (Giday et al. 2003; Ayyanar and Ignacimuthub, 2005; Uniyal et al. 2006; Mesfin et al. 2012). Participants indicated that they preferred mostly herbs because of their potency and fast regeneration, as compared to other life forms. The high percentage of herbs was also reported in some other studies (Upadhyay et al. 2007; Upadhyay et al. 2010; Megersa et al. 2013).

Among the plant families used, the most noteworthy in terms of number of species reported were Apiaceae (7 sp.), Asteraceae (6 sp.), Poaceae and Rosaceae (5 sp. each), and Lamiaceae (3 sp.) (Table 4 and Fig. 6), which was similar to the work of (Bibi et al. 2014; Tareen et al. 2016). The pharmacological significance of therapeutic plant families FIV is given in Fig. 7. Family Apiaceae had the peak (FIV) value (46.5), tailed by Asteraceae (37.5), Rosaceae (31), Lamiaceae (30.5) and Poaceae (29) (Table 4). Medicinal plant species of family Apiaceae, Asteraceae and Rosaceae are cited as important in many pharmacological works (e.g. Martin and Briones, 1999; Shad et al. 2013; Kayani et al. 2014; Tareen et al. 2016).

\section{Plant-parts used, preparation method and administration mode of therapeutic plants used for $D D s$}

In order to prepare various folk medicines, different parts of the plants were used, such as bark, flower, fruit, leaves, root, seed, and stem. The most frequently used plant parts were leaves $(43.18 \%)$ tailed by seeds $(29.54 \%)$, fruit $(22.72 \%)$ and flower (15.9\%) (Fig. 8). The common use of leaves has been also reported by Saikia et al, (2006), Dogan et al. (2013), Tareen et al, (2016), and Shah and Rahim (2017) likewise fruit and seeds were commonly used as reported by Rokaya et al. (2010) and Tareen et al. (2016) for the cure of DDs. Leaves are well-known for the synthesis of numerous active ingredients and pharmacologically more active than some other part (Rokaya et al. 2014; Ahmad et al. 2016; Shah and Rahim 2017). Furthermore, the utilization of leaves is less deleterious to the survival of a plant species as compared to the use of other parts (e.g. roots, stem, bark), or the use of entire plants (Abebe and Ayehu 1993; Giday et al, 2003; Zheng and Xing 2009). Moreover, leaves are collected more easily than other parts of plants (Giday et al. 2009).

Different plant parts were used direct/unprocessed, decoction, juice, powdered or any other form along with dietary items. Unprocessed leaves in fresh/dried form $(34.09 \%)$ were most commonly used for many DDs, tailed by powder (27.27\%), decoction (18.18\%) and cooked (15.91\%) (Fig. 9). 
Table. 2. Qualitative and quantitative ethno-medicinal data of therapeutic plants utilized for digestive disorders by the people of Laspur Valley.

\begin{tabular}{|c|c|c|c|c|c|c|c|c|c|c|c|}
\hline Family/Botanical Name (Voucher No.) & $\begin{array}{l}\text { Part/s } \\
\text { used }\end{array}$ & Diseases cured & Administration & Participants & UV & $\mathbf{F I}$ & $\mathbf{C l}$ & $\mathbf{N}_{\mathbf{r}}$ & $\mathbf{N}_{\mathbf{a}}$ & IAR & CAI \\
\hline \multicolumn{12}{|l|}{ AMARANTHACEAE } \\
\hline Amaranthus cruentus L. (LS-235) & Leaves & Laxative & Cooked & 13 & 0.076 & 0.065 & + & 13 & 1 & 1 & 6.5 \\
\hline \multicolumn{12}{|l|}{ APIACEAE } \\
\hline Carum carvi L. (LS-240) & Seeds & Stomachic & Herbal tea & 22 & 0.045 & 0.11 & ++ & 22 & 1 & 1 & 11 \\
\hline Carum copticum L. (LS-241) & $\begin{array}{l}\text { Leaves, } \\
\text { Flower \& } \\
\text { Seeds }\end{array}$ & Diarrhea & Decoction & 18 & 0.055 & 0.09 & + & 18 & 1 & 1 & 9 \\
\hline Coriandrum sativum L. (LS-245) & $\begin{array}{l}\text { Seeds \& } \\
\text { Leaves }\end{array}$ & Carminative & Powder & 57 & 0.017 & 0.285 & +++ & 57 & 1 & 1 & 28.5 \\
\hline Cuminum cyminum L. (LS-247) & $\begin{array}{l}\text { Seeds \& } \\
\text { Leaves }\end{array}$ & Appetizer & Cooked & 19 & 0.052 & 0.095 & + & 19 & 1 & 1 & 9.5 \\
\hline Daucus carota L. (LS-248) & Seeds & Stomachic & Herbal tea & 33 & 0.030 & 0.165 & ++ & 33 & 1 & 1 & 16.5 \\
\hline Ferula narthex L. (LS-250) & Stem & Stomachic & Direct & 14 & 0.071 & 0.07 & + & 14 & 1 & 1 & 7 \\
\hline Foiniculum vulgare Mill. (LS-251) & $\begin{array}{l}\text { Seeds \& } \\
\text { Leaves }\end{array}$ & Stomachic & Direct & 24 & 0.041 & 0.12 & ++ & 24 & 1 & 1 & 12 \\
\hline \multicolumn{12}{|l|}{ ASTERACEAE } \\
\hline Artemisia absinthium L. (LS-236) & Seeds & Stomachic & Powder & 17 & 0.058 & 0.085 & + & 17 & 1 & 1 & 8.5 \\
\hline Artemisia bigelovii A. Gray (LS-237) & $\begin{array}{l}\text { Leaves \& } \\
\text { Flowers }\end{array}$ & $\begin{array}{l}\text { Gastric problem \& } \\
\text { Stomachic }\end{array}$ & Powder & 23 & 0.086 & 0.115 & ++ & 23 & 2 & 0.95 & 10.925 \\
\hline Cichorium intybus L. (LS-243) & Roots & Vomiting & Decoction & 29 & 0.034 & 0.145 & ++ & 29 & 1 & 1 & 14.5 \\
\hline Lactuca sativa L. (LS-254) & Leaves & Appetizer & Direct & 43 & 0.023 & 0.215 & ++ & 43 & 1 & 1 & 21.5 \\
\hline Matricaria chamomilla L. (LS-258) & Flowers & $\begin{array}{c}\text { Stomachic \& } \\
\text { indigestion }\end{array}$ & Decoction & 22 & 0.091 & 0.11 & ++ & 22 & 2 & 0.95 & 10.45 \\
\hline Taraxacum officinale F.H. Wigg (LS-274) & Leaves & Constipation & Cooked & 29 & 0.034 & 0.145 & ++ & 29 & 1 & 1 & 14.5 \\
\hline \multicolumn{12}{|l|}{ BERBERIDACEAE } \\
\hline Berberis vulgaris L. (LS-238) & $\begin{array}{l}\text { Leaves \& } \\
\text { Fruit }\end{array}$ & Dyspepsia & Decoction & 54 & 0.018 & 0.27 & +++ & 54 & 1 & 1 & 27 \\
\hline \multicolumn{12}{|l|}{ BRASSICACEAE } \\
\hline Lepidium ruderale L. (LS-255) & Leaves & Dyspepsia & Direct & 11 & 0.090 & 0.055 & + & 11 & 1 & 1 & 5.5 \\
\hline Nasturtium officinale W.T. Aiton (LS-263) & Leaves & Dyspepsia & Cooked & 15 & 0.066 & 0.075 & + & 15 & 1 & 1 & 7.5 \\
\hline
\end{tabular}

Published: 19 October 2019

http://dx.doi.org/10.32859/era.18.32.1-18 
Ethnobotany Research and Applications

\begin{tabular}{|c|c|c|c|c|c|c|c|c|c|c|c|}
\hline \multicolumn{12}{|l|}{ CAPPARIDACEAE } \\
\hline Capparis spinosa L. (LS-239) & Flowers & Stomachic & Decoction & 16 & 0.062 & 0.08 & + & 16 & 1 & 1 & 8 \\
\hline \multicolumn{12}{|l|}{ CARYOPHYLLACEAE } \\
\hline Lepyrodiclis holosteoides (C.A.Mey.) (LS-256) & Leaves & Laxative & Direct & 15 & 0.066 & 0.075 & + & 15 & 1 & 1 & 7.5 \\
\hline \multicolumn{12}{|l|}{ CHENOPODIACEAE } \\
\hline Chenopodium album L. (LS-242) & Leaves & Laxative & Cooked & 36 & 0.027 & 0.18 & ++ & 36 & 1 & 1 & 18 \\
\hline \multicolumn{12}{|l|}{ CONVOLVULACEAE } \\
\hline Convolvulus arvensis L. (LS-244) & Leaves & Constipation & Cooked & 32 & 0.031 & 0.16 & ++ & 32 & 1 & 1 & 16 \\
\hline \multicolumn{12}{|l|}{ CUCURBITACEAE } \\
\hline Cucumis sativus L. (LS-246) & Fruit & Constipation & Direct & 25 & 0.040 & 0.125 & ++ & 25 & 1 & 1 & 12.5 \\
\hline \multicolumn{12}{|l|}{ EPHEDRACEAE } \\
\hline Ephedra gerardiana Wallich ex C.A. Meyer (LS-249) & $\begin{array}{l}\text { Whole } \\
\text { plant }\end{array}$ & Gastric problem & Decoction & 31 & 0.032 & 0.155 & ++ & 31 & 1 & 1 & 15.5 \\
\hline \multicolumn{12}{|l|}{ LAMIACEAE } \\
\hline Mentha arvensis L. (LS-259) & Leaves & Stomachic & Direct, Powder & 38 & 0.026 & 0.19 & ++ & 38 & 1 & 1 & 19 \\
\hline Mentha Iongifolia (L.) Huds. (LS-260) & Leaves & Stomachic & Direct, Powder & 43 & 0.023 & 0.215 & ++ & 43 & 1 & 1 & 21.5 \\
\hline Mentha spicata L. (LS-261) & $\begin{array}{l}\text { Leaves \& } \\
\text { flowers }\end{array}$ & $\begin{array}{c}\text { Stomachic, } \\
\text { appetizer \& } \\
\text { dyspepsia }\end{array}$ & Direct, Cooked & 53 & 0.056 & 0.265 & +++ & 53 & 3 & 0.96 & 25.44 \\
\hline \multicolumn{12}{|l|}{ MALVACEAE } \\
\hline Abelmoschus esculentus L. (LS-234) & Fruit & Dysentery & Direct & 21 & 0.047 & 0.105 & + & 21 & 1 & 1 & 10.5 \\
\hline Malva neglecta Wallr. (LS-257) & Leaves & Constipation & Decoction & 19 & 0.052 & 0.095 & + & 19 & 1 & 1 & 9.5 \\
\hline \multicolumn{12}{|l|}{ MORACEAE } \\
\hline Morus nigra L. (LS-262) & Fruit & Dyspepsia & Direct & 23 & 0.043 & 0.115 & ++ & 23 & 1 & 1 & 11.5 \\
\hline \multicolumn{12}{|l|}{ PLANTAGINACEAE } \\
\hline Plantago major L. (LS-266) & Seeds & $\begin{array}{c}\text { Constipation \& } \\
\text { diarrhea }\end{array}$ & Direct & 37 & 0.054 & 0.185 & ++ & 37 & 2 & 0.97 & 17.945 \\
\hline \multicolumn{12}{|l|}{ POACAE } \\
\hline Hordeum distichon L. (LS-252) & Seeds & Appetizer & Powder & 17 & 0.058 & 0.085 & + & 17 & 1 & 1 & 8.5 \\
\hline Hordeum vulgare L. (LS-253) & Seeds & $\begin{array}{c}\text { Stomachic \& } \\
\text { indigestion }\end{array}$ & Powder & 38 & 0.052 & 0.19 & ++ & 38 & 2 & 0.97 & 18.43 \\
\hline Panicum miliaceum L. (LS-264) & Seeds & Stomachic & Powder & 16 & 0.062 & 0.08 & + & 16 & 1 & 1 & 8 \\
\hline Pennisetum typhoideum (Burm. f.) Stapf (LS-265) & Seeds & Stomachic & Powder & 8 & 0.125 & 0.04 & + & 8 & 1 & 1 & 4 \\
\hline Zea mays L. (LS-277) & Seeds & Stomachic & Powder & 47 & 0.021 & 0.235 & ++ & 47 & 1 & 1 & 23.5 \\
\hline
\end{tabular}

Published: 19 October 2019

http://dx.doi.org/10.32859/era.18.32.1-18 
Ethnobotany Research and Applications

\begin{tabular}{|c|c|c|c|c|c|c|c|c|c|c|c|}
\hline \multicolumn{12}{|l|}{ POLYGONACEAE } \\
\hline Rumex longifolius DC. (LS-272) & Leaves & Laxative & Paste & 11 & 0.090 & 0.055 & + & 11 & 1 & 1 & 5.5 \\
\hline \multicolumn{12}{|l|}{ ROSACEAE } \\
\hline Prunus armeniaca L. (LS-267) & Fruit & Constipation & Syrup & 34 & 0.029 & 0.17 & ++ & 34 & 1 & 1 & 17 \\
\hline Pyrus malus L. (LS-268) & Fruit & Stomachic & Direct & 36 & 0.027 & 0.18 & ++ & 36 & 1 & 1 & 18 \\
\hline Rosa alba L. (LS-269) & Flower & Stomachic & Juice & 22 & 0.045 & 0.11 & ++ & 22 & 1 & 1 & 11 \\
\hline Rosa webbiana Wall ex. Royle. (LS-270) & Flower & Stomachic & Herbal tea & 24 & 0.041 & 0.12 & ++ & 24 & 1 & 1 & 12 \\
\hline Rubus fruticosus L. sens.str. (LS-271) & Fruit & $\begin{array}{l}\text { Carminative, } \\
\text { diarrhea \& } \\
\text { looseness of } \\
\text { intestine }\end{array}$ & Direct, powder & 27 & 0.111 & 0.135 & ++ & 27 & 3 & 0.92 & 12.42 \\
\hline \multicolumn{12}{|l|}{ SOLANACEAE } \\
\hline Solanum nigrum L. (LS-273) & Fruit & Stomachic & Powder & 37 & 0.027 & 0.185 & ++ & 37 & 1 & 1 & 18.5 \\
\hline \multicolumn{12}{|l|}{ VIOLACEAE } \\
\hline Viola rupestris F.W. Schmidt. (LS-275) & Flowers & Purgative & Decoction & 33 & 0.047 & 0.105 & ++ & 33 & 2 & 0.97 & 10.18 \\
\hline \multicolumn{12}{|l|}{ VITACEAE } \\
\hline Vitis vinifera L. (LS-276) & Fruit & Gastric problem & Direct & 13 & 0.076 & 0.065 & + & 13 & 1 & 1 & 6.5 \\
\hline
\end{tabular}

\section{Use Value $=U V$}

Familiarity Index=FI

Consensus Index $=\mathrm{Cl}$

Informant Agreement Ratio=IAR

Cultural Agreement Index $=\mathrm{CAI}$ 
Table 3. Listing some important folk herbal recipes

\begin{tabular}{|c|c|}
\hline Plant Name & Herbal Recipes \\
\hline Amaranthus cruentus L. & $\begin{array}{l}\text { Young leaves are plucked, washed and cooked; these cooked leaves are used } \\
\text { as laxative. }\end{array}$ \\
\hline Artemisia bigelovii A. Gray & $\begin{array}{l}\text { Leaves and inflorescence are ground to make powder; this is used for gastric } \\
\text { problems and stomachache. }\end{array}$ \\
\hline Artemisia absinthium L. & $\begin{array}{l}\text { One teaspoon full of powdered seeds is taken with a glass of water to cure } \\
\text { abdominal pain. }\end{array}$ \\
\hline Berberis vulgaris $\mathrm{L}$. & $\begin{array}{l}\text { Leaves and fruits are collected, juice is extracted and filtered, which can be } \\
\text { taken orally for the treatment of dyspepsia. }\end{array}$ \\
\hline Capparis spinosa L. & $\begin{array}{l}\text { Floral buds are collected, dried, mashed with wheat flour and cooked to prepare } \\
\text { aqueous extract called Kavirough, which is efficient for abdominal pain. }\end{array}$ \\
\hline Carum carvi L. & Seeds are boiled in water to make a herbal tea, which is used for stomachache. \\
\hline Carum copticum L. & $\begin{array}{l}\text { The aromatic seeds, leaves and flowers are boiled in milk with a little salt and } \\
\text { given to the patients of diarrhea }\end{array}$ \\
\hline Cichorium intybus L. & $\begin{array}{l}\text { The root of this plant is dug out, washed, chopped and boiled with water. This } \\
\text { aqueous extract is useful for vomiting. }\end{array}$ \\
\hline Chenopodium album L. & $\begin{array}{l}\text { Young leaves are plucked washed and cooked; these cooked leaves are used } \\
\text { as laxative and to cure constipation. }\end{array}$ \\
\hline Coriandrum sativum L. & $\begin{array}{l}\text { The dried seeds and leaves are powdered and taken with water about half } \\
\text { teaspoon as a carminative after meal. }\end{array}$ \\
\hline Convolvulus arvensis $\mathrm{L}$. & $\begin{array}{l}\text { The fresh leaves are collected and boiled in water and chopped. The paste is } \\
\text { mixed with tomato, onion, ginger, garlic, salt (as required) and then fried in oil. } \\
\text { This gravy is used for curing constipation. The doze is usually } 2-3 \text { times a day. }\end{array}$ \\
\hline Daucus carota L. & $\begin{array}{l}\text { The dried } 10-15 \text { seeds are boiled in water to form herbal tea; this tea is used for } \\
\text { the cure of abdominal pain. }\end{array}$ \\
\hline $\begin{array}{l}\text { Ephedra gerardiana Wallich ex C. } \\
\text { A. Meyer }\end{array}$ & $\begin{array}{l}\text { Boiled in water, crushed and aqueous extract is obtained, called Gholja in } \\
\text { Khowar language, which is used to treat gastric problem. }\end{array}$ \\
\hline Ferula narthex L. & $\begin{array}{l}\text { Young stems are cut which result in oozing of milky exudates. This exudate } \\
\text { solidifies after one day and is locally called Hing, which is used against } \\
\text { toothache, stomachache. }\end{array}$ \\
\hline Foeniculum vulgare L. & Seeds and fresh leaves are chewed for abdominal pain. \\
\hline Hordeum vulgare $\mathrm{L}$. & $\begin{array}{l}\text { The seeds are ground to make powder; this powder is used for bread making, } \\
\text { which is recommended for stomachache and indigestion. }\end{array}$ \\
\hline Matricaria camomilla L. & $\begin{array}{l}\text { The flower heads of this plant are collected, dried, boiled in water and the } \\
\text { decoction is given to the patients with abdominal pain and indigestion. }\end{array}$ \\
\hline Mentha spicata L. & $\begin{array}{l}\text { The leaves and flowers meshed with wheat flour are cooked to prepare } \\
\text { Suspruough, which is eaten as appetizer and to cures dyspepsia, stomach pain. }\end{array}$ \\
\hline $\begin{array}{l}\text { Pennisetum typhoideum (Burm. } \\
\text { f.) Stapf }\end{array}$ & $\begin{array}{l}\text { The seeds are ground to form powder and then bread is made from it. This is } \\
\text { used to treat stomachache. }\end{array}$ \\
\hline Plantago major L. & $\begin{array}{l}\text { About one teaspoon seeds are soaked in one cup water or milk, his is used 3-4 } \\
\text { times a day to treat constipation and diarrhea. }\end{array}$ \\
\hline Prunus armeniaca L. & $\begin{array}{l}\text { The ripe fruits are dried, soaked in water and sweet syrup is obtained, this syrup } \\
\text { is used for constipation. }\end{array}$ \\
\hline Rosa webbiana Wall ex. Royle. & $\begin{array}{l}\text { The petals of these plants are collected, petals are dried, crushed and } \\
\text { powdered; this powder in one teaspoon is poured into tea, due to which herbal } \\
\text { tea is made for stomachache. }\end{array}$ \\
\hline Rumex longifolius DC. & $\begin{array}{l}\text { The fresh leaves are collected, boiled, cut, and the past are mixed with tomato, } \\
\text { onion, ginger, garlic, salt (as required) and then fried in oil, this gravy is used as } \\
\text { laxative when eaten as vegetable. }\end{array}$ \\
\hline Viola rupestris F.W. Schmidt. & $\begin{array}{l}\text { Flowers are dried and powdered and boiled in water to make decoction this is } \\
\text { used as astringent (Kabaz) and purgative (dast awar). }\end{array}$ \\
\hline
\end{tabular}




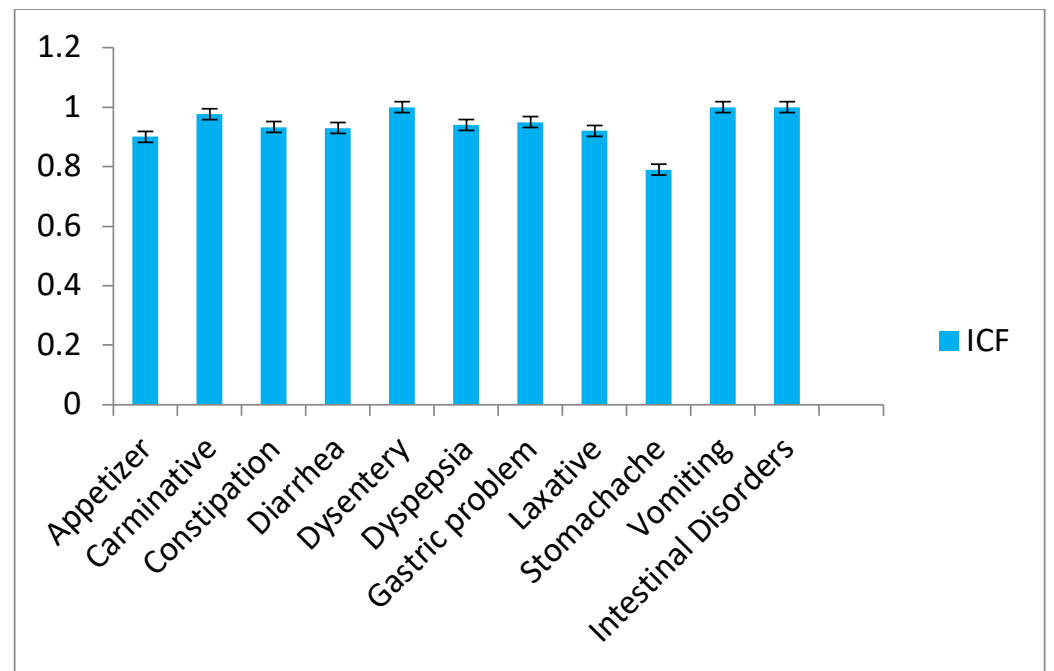

Fig. 4. Digestive disorders on the basis of Informant Consensus Factor (ICF)

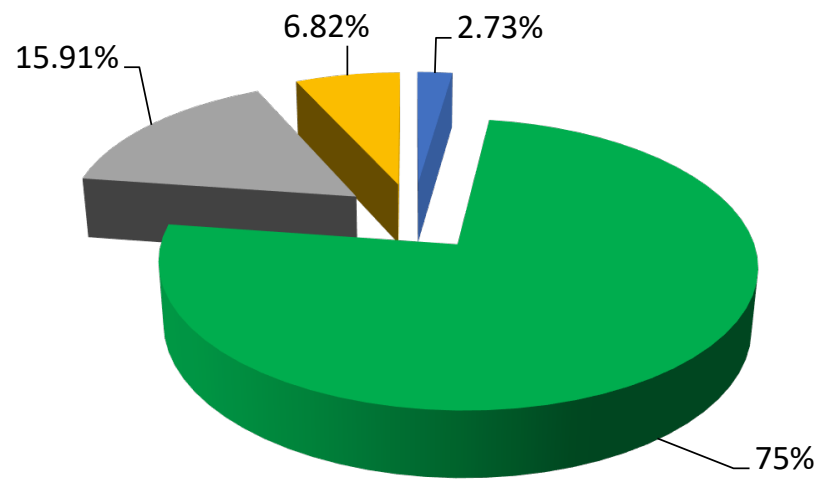

Climber

Herb

Shrub

Tree

Fig. 5. Percentage of life forms of medicinal plants

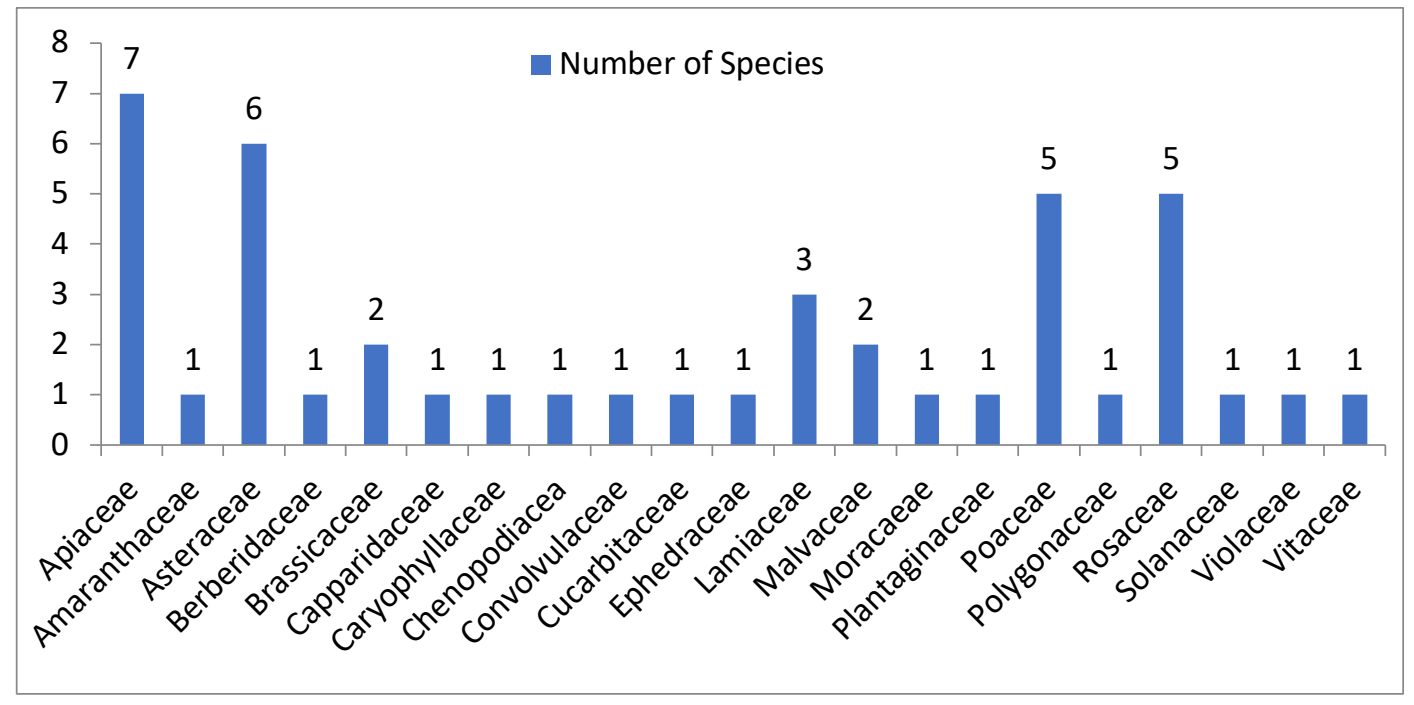

Fig. 6. Number of species in each family 


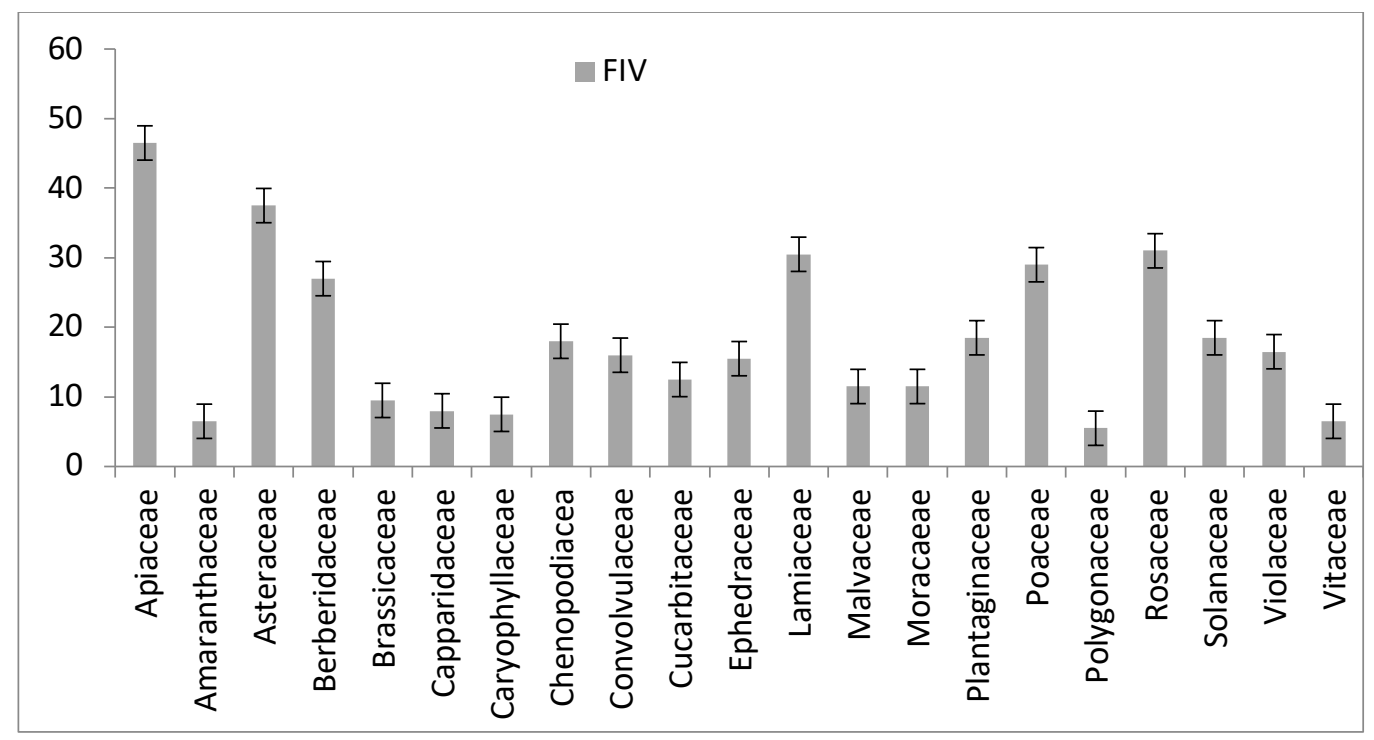

Fig. 7. Family Importance Value (FIV) based on participant's answers

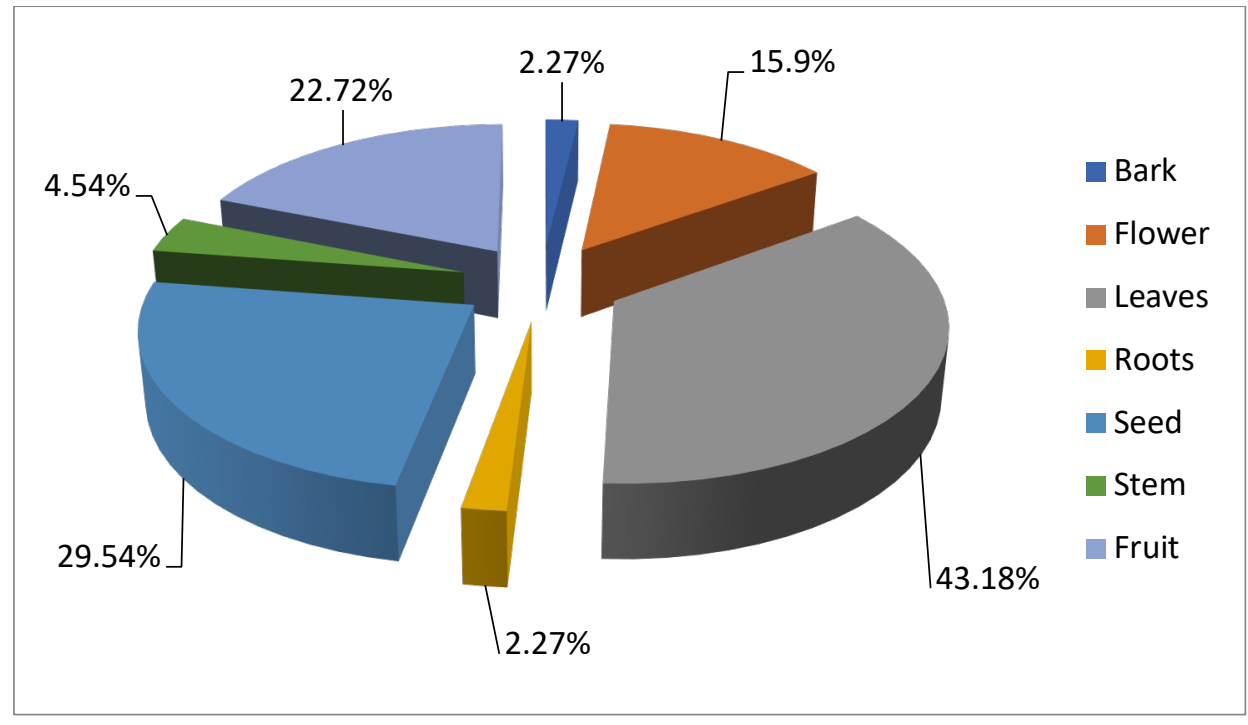

Fig. 8. Plant parts used for medicinal purposes

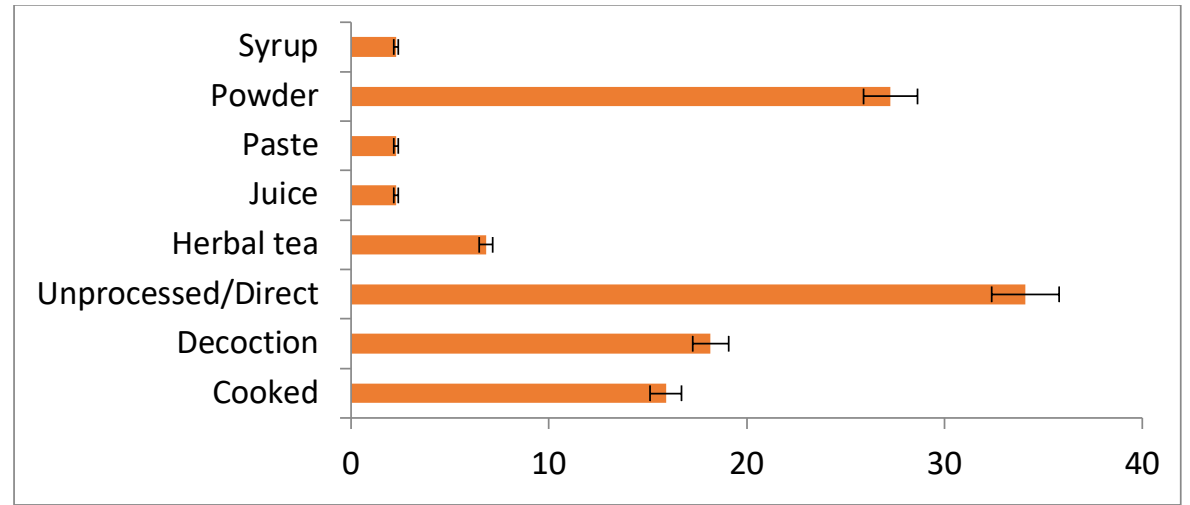

Fig. 9. Modes of preparation of medicinal plants 
Familiarity Index and Use value of medicinal plant species for DDs

All medicinal plant species used for DDs documented through interviews are listed in Table 2. Statistical tools were applied to quantitatively analyze the ethnomedicinal data about DDs.

\section{Familiarity Index (FI)}

The familiarity index $(\mathrm{FI})$ was used to determine the general practicality of the cited medicinal plant in the viewpoint of DDs (Tabuti et al. 2004; Hoffman and Gallaher, 2007; Kidane et al. 2014). FI values were led by Coriandrum sativum $(0.285,57$ citations and 1 use category), followed by Berberis vulgaris (0.27), Mentha spicata $(0.265$, with 53 citations and 3 use categories), Zea mays L. (0.235, 47 citations and 1 use category). Least values of $\mathrm{FI}$ were found for Pennisetum typhoideum (0.04, with 8 citations and single use report), Rumex longifolius and Lepidium ruderale $(0.05,11$ use reports and one single use category) (Table 3 and Fig. 10).

\section{Use Value (UV)}

It was noted that the use values of therapeutic plants fluctuated from 0.017-0.125 (Table 2 and Fig. 11). The therapeutic plants with highest use values were Pennisetum typhoideum (0.125), Rubus fruticosus (0.111), and Matricaria chamomilla (0.091). On the other hand, therapeutic plants with least use values were Coriandrum sativum (0.017), Berberis vulgaris (0.018), and Zea mays (0.021).

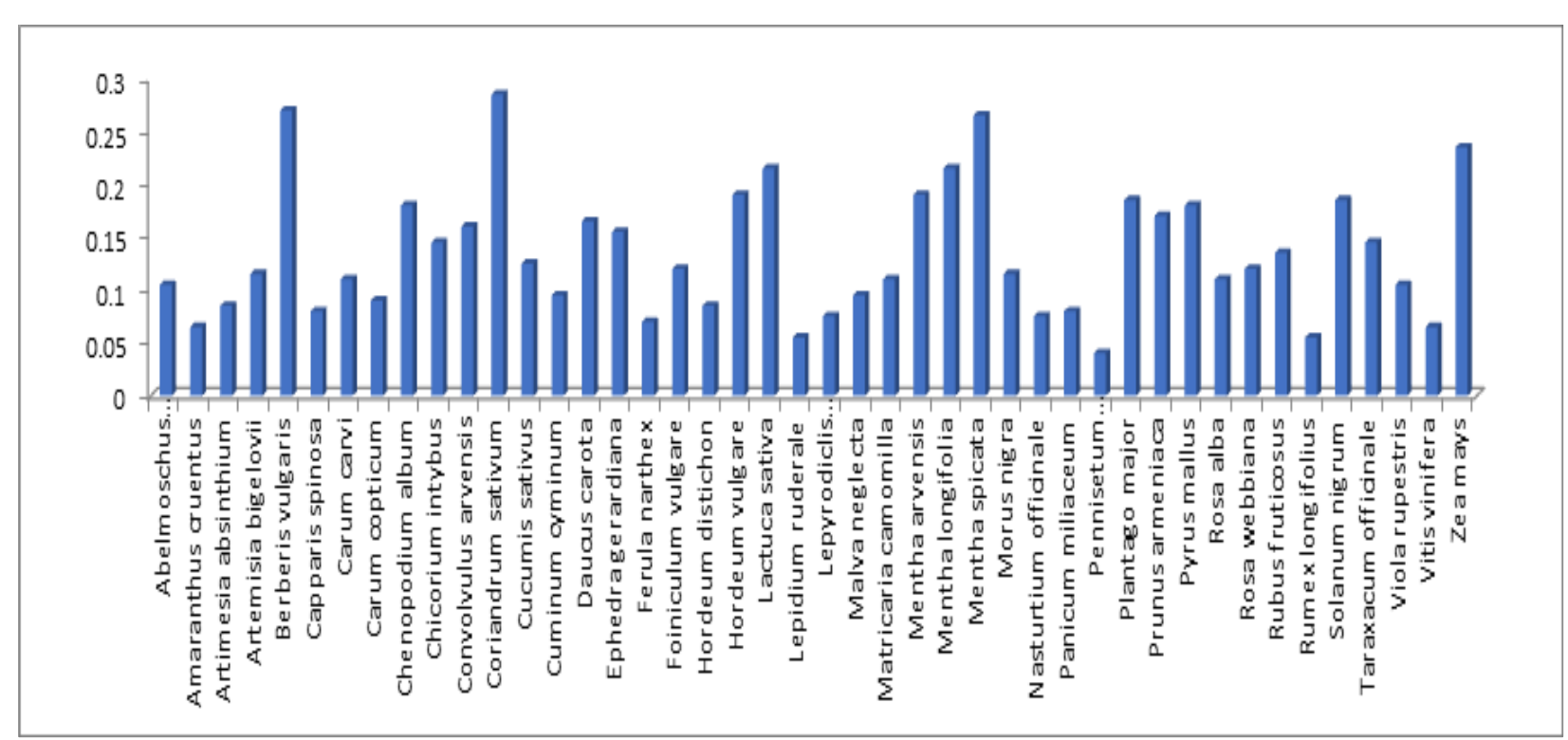

Fig. 10. Familiarity index (FI) of therapeutically valuable plants

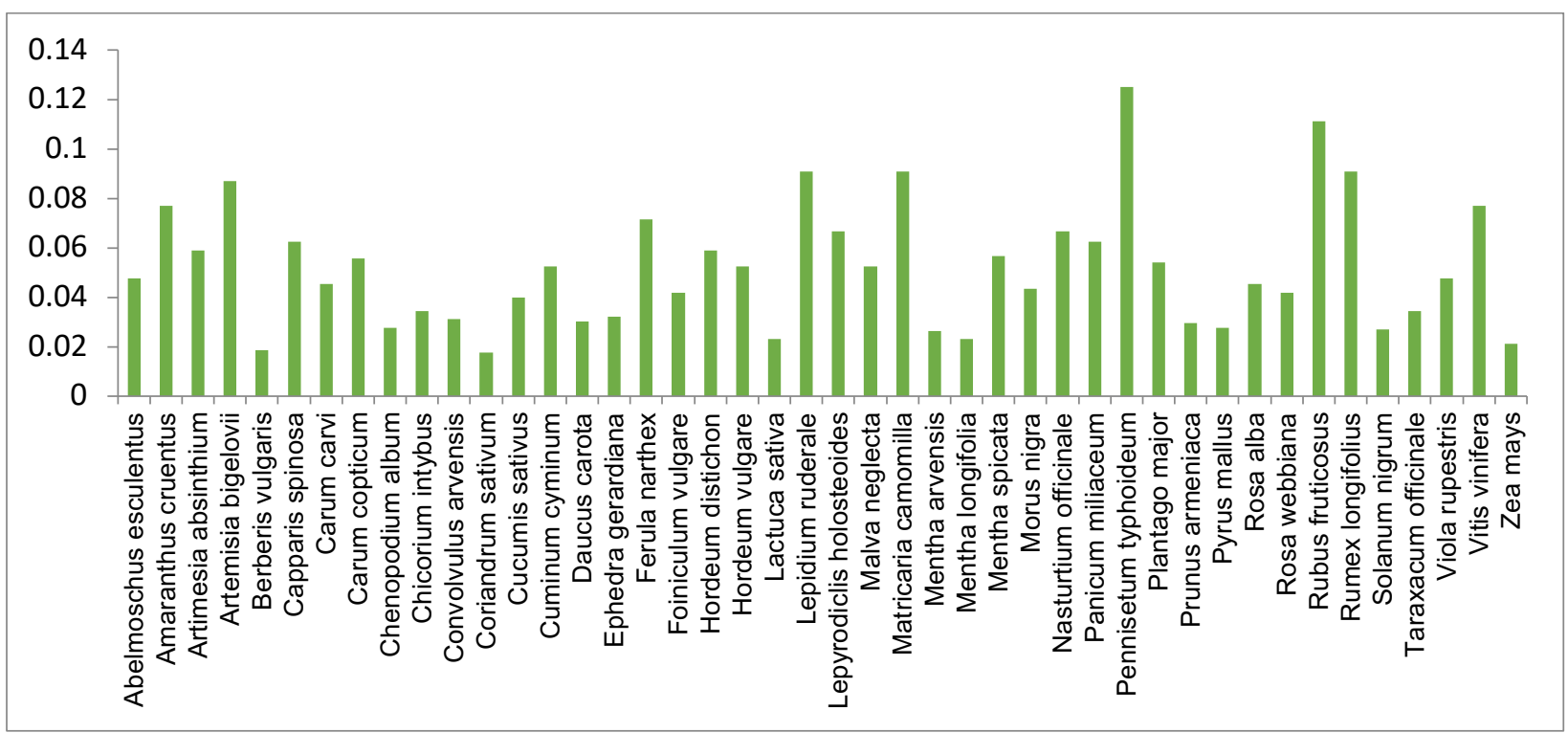

Fig. 11. Use value (UV) of therapeutically valuable plants 
Table. 4. Family importance value of medicinally important families

\begin{tabular}{lccc}
\hline Family Name & $\begin{array}{c}\text { No. of } \\
\text { species }\end{array}$ & $\begin{array}{c}\text { No. of } \\
\text { informants }\end{array}$ & FIV \\
\hline Apiaceae & 7 & 93 & 46.5 \\
Amaranthaceae & 1 & 13 & 6.5 \\
Asteraceae & 6 & 75 & 37.5 \\
Berberidaceae & 1 & 54 & 27 \\
Brassicaceae & 2 & 19 & 9.5 \\
Capparidaceae & 1 & 16 & 8 \\
Caryophyllaceae & 1 & 15 & 7.5 \\
Chenopodiaceae & 1 & 36 & 18 \\
Convolvulaceae & 1 & 32 & 16 \\
Cucurbitaceae & 1 & 25 & 12.5 \\
Ephedraceae & 1 & 31 & 15.5 \\
Lamiaceae & 3 & 61 & 30.5 \\
Malvaceae & 2 & 23 & 11.5 \\
Moracaeae & 1 & 23 & 11.5 \\
Plantaginaceae & 1 & 37 & 18.5 \\
Poaceae & 5 & 58 & 29 \\
Polygonaceae & 1 & 11 & 5.5 \\
Rosaceae & 5 & 62 & 31 \\
Solanaceae & 1 & 37 & 18.5 \\
Violaceae & 1 & 33 & 16.5 \\
Vitaceae & 1 & 13 & 6.5 \\
\hline & & &
\end{tabular}

\section{Comparison with previously publish work}

In the present work Abelmoschus esculentus was reported to be used for dysentery and the same plant was reported by Akhtar et al. (2013) used as emollient, demulcent and diuretic. We reported Artemisia absinthium to be used as stomachic, while the plant was documented to treat tuberculosis and cough, Kayani et al. (2014), and for skin problems and itching, Bano et al. (2014). Berberis vulgaris was found to treat dyspepsia in our study, while reported as stomachic, Shah et al. (2016). Similarly, Capparis spinosa was documented, us as stomachic, while it was used against malaria in the study of Sher et al. (2016), and for joint pain, Bano et al. (2014). We found Carum carvi to be used for stomachache, while Bano et al. (2014) reported its uses for gastric problems, sore throat, and rheumatism and Sher et al. (2016) reported its use for stomachache and indigestion. In our study we reported Carum copticum for diarrhea (dysentery, Tariq et al. 2015), Chenopodium album as a laxative (appetite and abdominal pain, Ullah et al. 2013) Cichorium intybus for vomiting (gastrointestinal problems, Bano et al. 2014; aphrodisiac and cooling, Barkatullah et al. 2015) Convolvulus arvensis for treatment of constipation (purgative,, Sher et al. 2011; purgative, Adnan et al. 2014; constipation, Abbasi et al. 2010), Coriandrum sativum as a carminative (carminative, Adnan et al. 2014; carminative and for indigestion, Tariq et al. 2015), Cucumis sativus for constipation (cooling, diuretic, tonic, vermifuge, diuretic and purgative, Marwat et al. 2009), Cuminum cyminum as an appetizer (stomach problem, Huassain and Ghani, 2008), Daucus carota as a stomachic (regulate menstruation, Muhammad and Khan, 2008; carminative and for dysentery, Jan et al. 2008), Ephedra gerardiana for gastric problem (joint pain, Noor et al. 2014; rheumatism and respiratory disorders, Bano et al. 2014; asthma and tuberculosis, Shinwari and Gilani, 2003) Ferula narthex as a stomachic (cough, asthma, toothache, gastric problems and anti-constipation, Shinwari and Gilani, 2003), Foeniculum vulgare was used as stomachic (stomach-ache, Bano et al. 2014; bronchitis and abdominal pain, Sher et al. 2016; carminative, constipation, diarrhea, dyspepsia, stomachic, Shah et al. 2016), Hordeum vulgare as a stomachic and for indigestion (cathartic and purgative, Shah and Khan, 2006; jaundice, Khan et al. 2011), Lactuca sativa as an appetizer (blood purification, Adnan et al. 2014; skin diseases, syphilis and rheumatism, Shah and Khan, 2006), Malva neglecta to cure constipation (stomach pain, Tariq et al. 2015; boils, bitter mouth feel, constipation, expulsion of retained placenta, Shah et al. 2016), Matricaria chamomilla used as stomachache and indigestion (for wounds and rheumatic pain, Bano et al. 2014), Mentha arvensis for stomachache (antiemetic, carminative, stomachic, fat burner, hyperacidity, bitter mouth feel, cough suppressant, cooling, diarrhea, toothache, Shah et al. 2016; emollient, aperient, demulcent, Shah and Khan, 2006), Mentha longifolia for stomach ache (anti-stomachache and carminative, Barkatullah et al. 2015; cholera, diarrhea and vomiting, Abbasi et al. 2010), Mentha spicata as a stomachic, appetizer and for dyspepsia (stomachache and carminative, diarrhea and dysentery, Jan et al. 2008; dyspepsia and carminative Hazrat et al. 2011), Morus nigra for dyspepsia (analgesic, Adnan et al. 2014; antistomachache, Barkatullah et al. 2015), Nasturtium officinale used to cure dyspepsia (febrifuge and antistomachache, Barkatullah et al. 2015; purgative and emetic, Sher et al. 2011), Plantago major used for constipation and diarrhea (cool and wash the mouth, Adnan et al. 2014; wound healing and laxative, Barkatullah et al. 2015; laxative, dysentery and mouth diseases, Jan et al. 2008), Prunus armeniaca used as remedy for constipation (carminative, appetizer and help control stomach acidity, Khan and Ahmad, 2015; anticancer, Akhter et al. 2013), Pyrus 
malus as stomac, to lower uric acid, blood pressure and rheumatism problems in the community (as tonic to invigorating the body and strengthen bones, Ishtiaq et al. 2012; to potent vigor, blood purifier, anticardiovascular diseases, Ishtiaq et al. 2015). Rosa alba was used as stomachic (lowering blood glucose, Ahmad et al. 2009), Rosa webbiana as stomachic, to cure piles (Barkatullah et al. 2015); as stomachic (Ullah et al. 2013) for fever, cough and sore throat (Khan and Khatoon, 2007), Rubus fruticosus as carminative, diarrhea and looseness of intestine, reported as aphrodisiac and carminative (Barkatullah et al. 2015); for diarrhea (Jan et al. 2008), Solanum nigrum as a stomachic (jaundice and blood purification, Mahmood et al. 2011b; skin inflammation and against fever, Akhtar et al. 2013), Taraxacum officinale for constipation (analgesic and astringent, Shah and Khan, 2006; jaundice, Abbasi et al. 2010), Viola rupestris used as astringent and purgative (chest infection, Ahmad et al. 2016), Vitis vinifera for gastric problems (common cold, relax body and brain, stomach diseases, Marwat et al. 2009; carminative, Adnan et al. 2014), and Zea mays used as stomachic (diabetes, Ahmad et al. 2004; Kidney stones, Akhtar and Begum, 2009; kidney stones and inflammation of urinary system, Mahmood et al. 2004).

\section{The most versatile medicinal family}

To find out the most versatile medicinal family, Family Importance Value (FIV) was used (Table 4). In the present work the most important family on the basis of medicinal value was Apiaceae with FIV value (46.5) followed by Asteraceae (37.5), Rosaceae (31) and Lamiaceae (30.5). Familiarity Index (FI) values demonstrated high proportion of recurrence of Coriandrum sativum referred by the native informants, though, Consensus Index $\mathrm{Cl}$ showed agreement on the significance of Coriandrum sativum as a vital, well-known therapeutic plant utilized in the study area to cure DDs.

\section{Medicinal importance of plants used to treat DDs} In the study we recorded 49 different DDs and those were grouped into 11 different aliments/conditions (Table 5, Fig. 4). Informant's consensus on the usage of medicinal plants for DDs was elucidated through the ICF. The range of ICF has been from 0 1 (Table 5). The ailment groups with maximum ICF are Dysentery, Vomiting and Intestinal Disorder (1.0 each), followed by Carminative (0.97), Gastric problems (0.95), Dyspepsia (0.94 each), Constipation and Diarrhea (0.93 each) Laxative (0.92), Appetizer (0.90) and Stomachache (0.79).
Table 5. Informant consensus factor (ICF) of medicinal plants for various digestive disorders classes

\begin{tabular}{lccc}
\hline Disease Category & $\mathbf{n}_{\mathbf{t}}$ & $\mathbf{n}_{\mathbf{u r}}$ & ICF \\
\hline Appetizer & 4 & 31 & 0.90 \\
Carminative & 2 & 43 & 0.97 \\
Constipation & 6 & 76 & 0.93 \\
Diarrhea & 3 & 32 & 0.93 \\
Dysentery & 1 & 21 & 1.00 \\
Dyspepsia & 5 & 69 & 0.94 \\
Gastric problem & 3 & 44 & 0.95 \\
Laxative & 5 & 51 & 0.92 \\
Stomachache & 18 & 82 & 0.79 \\
Vomiting & 1 & 29 & 1.00 \\
Intestinal Disorder & 1 & 9 & 1.00 \\
\hline
\end{tabular}

Nur $=$ Total number of reports of the use category in inquiry

$\mathrm{Nt}=$ Total number of species used in this category

\section{Conclusions}

This work was conducted to document how local communities of Laspur Valley, Pakistan treat DDs with medicinal plant species. A total of 44 therapeutic plant species belonging to 21 families was found to be used to treat one or more DDs. After literature review, to the best of our knowledge, many medicinally important plants were documented for the first time from Pakistan: Amaranthus cruentus, Artemisia bigelovii, Hordeum distichon, Lepidium ruderale, Lepyrodiclis holosteoides, Panicum miliaceum, Pennisetum typhoideum, and Rumex longifolius. Similarly, in this work some plants were reported for the first time to cure DDs, such as, Abelmoschus esculentus which was reported to be used for dysentery, Artemisia absinthium used as stomachic, Berberis vulgaris to treat dyspepsia, and others, such as Capparis spinosa, Cucumis sativus, Ephedra gerardiana, Lactuca sativa, Matricaria chamomilla, Pyrus malus, Rosa alba, Solanum nigrum, Taraxacum officinale, and Zea mays. The population of the study area clearly holds different ethnomedicinal knowledge from other regions in Pakistan.

\section{Declarations}
Abbreviations:
$\mathrm{DD}=$ Digestive disorder
UV = Use Value
$\mathrm{FI}=$ Familiarity Index
FIV = Family Importance Value
ICF = Informant Consensus Factor 
Ethics approval and consent to participate: Before conducting interviews, the individual prior informed consent was obtained from all participants. No further ethics approval was required. All work conducted was carried out under the stipulations of the Nagoya Protocol on Access to Genetic Resources and the Fair and Equitable Sharing of Benefits Arising from their Utilization to the Convention on Biological Diversity. The right to use and authorship of any traditional knowledge of all participants is maintained, and any use of this information, other than for scientific publication, does require additional prior consent of the traditional owners, as well as a consensus on access to benefits resulting from subsequent use.

Consent for publication: Not applicable - no personal data are included in this manuscript.

Funding: This study was no funding body for this research work.

\section{Availability of data and materials}

The raw data without names of participants are available from the authors.

\section{Author's contributions}

SW and HAJ designed the study; SW conducted the fieldwork, SW and HAJ conducted the main statistical analysis and wrote the manuscript, SW, HAJ and RWB revised the data analysis and the manuscript; all authors read, corrected and approved the manuscript.

Competing financial interests: The authors declare that they have no competing financial interest.

\section{Acknowledgements}

We are thankful to the local communities of Laspur valley for participating in the field survey and providing us the valuable information.

\section{Lierature cited}

Abbasi AM, Khan MA, Ahmed M, Zafar M. 2010. Herbal medicines used to cure various ailments by the inhabitants of Abbottabad district, North West Frontier Province, Pakistan. Indian Journal of Traditional Knowledge. 9(1):175-183.

Abbasi AM, Khan MA, Shah MH, Shah MM, Pervez A, Ahmad M. 2013. Ethnobotanical appraisal and cultural values of medicinally important wild edible vegetables of Lesser Himalayas-Pakistan. Journal Ethnobiology and Ethnomedicine. 9(1):66.
Abebe D, Ayehu A. 1993. Medicinal plants and enigmatic health practices of Northern Ethiopia. B.S.P.E., Addis Ababa, Ethiopia.

Adnan M, Ullah I, Tariq A, Murad W, Azizullah A, Khan AL, Ali, N. 2014. Ethnomedicine use in the war affected region of northwest Pakistan. Journal of Ethnobiology and Ethnomedicine. 10(1):16.

Ahmad M, Khan MA, Arshad M, Zafar M. 2004. Ethnophytotherapical approaches for the treatment of diabetes by the local inhabitants of district Attock (Pakistan). Ethnobotonical Leaflets. 1:7.

Ahmad M, Khan MPZ, Mukhtar A, Zafar M, Sultana S, Jahan S. 2016. Ethnopharmacological survey on medicinal plants used in herbal drinks among the traditional communities of Pakistan. Journal of Ethnopharmacology. 184:154-186.

Ahmad M, Qureshi R, Arshad M, Khan MA, Zafar M. 2009. Traditional herbal remedies used for the treatment of diabetes from district Attock (Pakistan). Pakistan Journal of Botany. 41(6):2777-2782.

Akerreta S, Cavero RY, Calvo MI. 2007. First comprehensive contribution to medical ethnobotany of Western Pyrenees. Journal of Ethnobiology and Ethnomedicine. 3(1):26.

Akhtar N, Begum S. 2009. Ethnopharmacological important plants of Jalala, district Mardan, Pakistan. Pakistan Journal of Plant Sciences. 15(2):95-100.

Akhtar N, Rashid A, Murad W, Bergmeier E. 2013. Diversity and use of ethno-medicinal plants in the region of Swat, North Pakistan. Journal of Ethnobiology and Ethnomedicine. 9(1):25.

Ali H, Qaiser M. 2009. The ethnobotany of Chitral valley, Pakistan with particular reference to medicinal plants. Pakistan Journal of Botany. 41(4):2009-2041.

Ayyanar M, Ignacimuthu S. 2005. Traditional knowledge of Kani tribals in Kouthalai of Tirunelveli hills, Tamil Nadu, India. Journal of Ethnopharmacology. 102(2):246-255.

Bano A, Ahmad M, Hadda TB, Saboor A, Sultana S, Zafar M, Khan MPZ, Arshad M, Ashraf MA. 2014a. Quantitative ethnomedicinal study of plants used in the Skardu valley at high altitude of KarakoramHimalayan range, Pakistan. Journal of Ethnobiology and Ethnomedicine. 10(1):43.

Bano A, Ahmad M, Zafar M, Sultana S, Rashid S, Khan MA. 2014. Ethnomedicinal knowledge of the most commonly used plants from Deosai Plateau, Western Himalayas, Gilgit Baltistan, Pakistan. Journal of Ethnopharmacology. 155(2):1046-1052.

Baral SR, Kurmi PP. 2006. Compendium of medicinal plants in Nepal. Mrs Rachana Publishers, Kathmandu, Nepal, 2006. pp-534. 
Barkatullah IM, Rauf A, Hadda TB, Mubarak MS, Patel S. 2015. Quantitative ethnobotanical survey of medicinal flora thriving in Malakand Pass Hills, Khyber Pakhtunkhwa, Pakistan. Journal of Ethnopharmacology. 169:335-46.

Bibi S, Sultana J, Sultana H, Malik RN. 2014. Ethnobotanical uses of medicinal plants in the highlands of Soan Valley, Salt Range, Pakistan. Journal of Ethnopharmacology. 155(1):352-361.

Butt MA, Ahmad M, Fatima A, Sultana S, Zafar M, Yaseen G, Ashraf MA, Shinwari ZK, Kayani S. 2015. Ethnomedicinal uses of plants for the treatment of snake and scorpion bite in Northern Pakistan. Journal of Ethnopharmacology. 168:164-181.

Dogan Y, Ugulu I, Durkan N. 2013. Wild edible plants sold in the local markets of Izmir, Turkey. Pakistan Journal of Botany. 45(S1):177-184.

Giday M, Asfaw Z, Woldu Z. 2009. Medicinal plants of the Meinit ethnic group of Ethiopia: an ethnobotanical study. Journal of Ethnopharmacology. 124(3):513-521.

Giday M, Asfaw Z, Elmqvist T, Woldu Z. 2003. An ethnobotanical study of medicinal plants used by the Zay people in Ethiopia. Journal of Ethnopharmacology. 85(1):43-52.

Giday M, Asfaw Z, Woldu Z, Teklehaymanot T. 2009. Medicinal plant knowledge of the Bench ethnic group of Ethiopia: an ethnobotanical investigation. Journal of Ethnobiology and Ethnomedicine. 5(1):34.

Gilani SA, Qureshi RA, Farooq U. 2001. Ethnobotanical studies of Ayubia national park district Abbottabad, Pakistan. Journal of Biological Science. 1(4):284-286.

Haq I. 1983. Medicinal Plants-Report of Committee on Economic and Therapeutic importance of Medicinal Plants. Ministry of Health. Government of Pakistan.

Hazrat A, Nisar M, Shah J, Ahmad S. 2011. Ethnobotanical study of some elite plants belonging to Dir, Kohistan valley, Khyber Pukhtunkhwa, Pakistan. Pakistan Journal of Botany. 43(2):787-795.

Heinrich M, Ankli A, Frei B, Weimann C, Sticher O. 1998. Medicinal plants in Mexico: Healers' consensus and cultural importance. Social Science and Medicine. 47(11):1859-1871.

Heinrich M, Rimpler H, Barrera NA. 1992. Indigenous phytotherapy of gastrointestinal disorders in a lowland Mixe community (Oaxaca, Mexico): Ethnopharmacologic evaluation. Journal of Ethnopharmacology. 36(1):63-80.

Hoffman B, Gallaher T. 2007. Importance indices in ethnobotany. Ethnobotany Research and Applications. 5:201-218.
Hussain F, Khaliq A, Durrani MJ. 1996. Ethnobotanical studies on some plants of Dabargai Hills. Swat. In Proceedings of First Training Workshop on Ethnobotany and its application to Conservation, 207-215.

Ishtiaq M, Mahmood A, Maqbool M. 2015. Indigenous knowledge of medicinal plants from Sudhanoti district (AJK), Pakistan. Journal of Ethnopharmacology. 168:201-207.

Ishtiaq M, Mumtaz AS, Hussain T, Ghani A. 2012. Medicinal plant diversity in the flora of Leepa Valley, Muzaffarabad (AJK), Pakistan. African Journal of Biotechnology. 11(13):3087-3098.

Jan G, Khan MA, Gul F. 2008. Ethnomedicinal plants used against diarrhea and dysentery in Dir Kohistan valley (NWFP), Pakistan. Ethnobotany Leaflets. 1:84.

Jordan SA, Cunningham DG, Marles RJ. 2010. Assessment of herbal medicinal products: challenges, and opportunities to increase the knowledge base for safety assessment. Toxicology and Applied Pharmacology. 243(2):198-216.

Kayani S, Ahmad M, Sultana S, Shinwari ZK, Zafar M, Yaseen G, Hussain M, Bibi T. 2015. Ethnobotany of medicinal plants among the communities of alpine and sub-alpine regions of Pakistan. Journal of Ethnopharmacology. 164:186-202.

Kayani S, Ahmad M, Zafar M, Sultana S, Khan MPZ, Ashraf MA, Hussain J, Yaseen G. 2014. Ethnobotanical uses of medicinal plants for respiratory disorders among the inhabitants of Gallies-Abbottabad, Northern Pakistan. Journal of Ethnopharmacology. 156:47-60.

Khan AA, Zaidi SH. 1991. Cultivation process of Mentha arvensis Linn. Pakistan Journal of Forestry. 41(4):170-172.

Khan B, Abdukadir A, Qureshi R, Mustafa G. 2011. Medicinal uses of plants by the inhabitants of Khunjerab National Park, Gilgit, Pakistan. Pakistan Journal of Botany.43(5):2301-2310.

Khan MPZ, Ahmad M. 2015. Traditional preference of Wild Edible Fruits (WEFs) for digestive disorders (DDs) among the indigenous communities of Swat Valley-Pakistan. Journal of Ethnopharmacology. 174:339-354.

Khan SW, Khatoon S. 2007. Ethno botanical studies on useful trees and shrubs of Haramosh and Bugrote valleys In Gilgit Notheren areas of Pakistan. Pakistan Journal of Botany. 39(3):699-710.

Kidane B, van Andel T, van der Maesen LJG, Asfaw Z. 2014a. Use and management of traditional medicinal plants by Maale and Ari ethnic communities in southern Ethiopia. Journal of Ethnobiology and Ethnomedicine. 10(1):46. 
Kidane B, Van der Maesen LJG, van Andel T, Asfaw Z, Sosef MSM. 2014b. Ethnobotany of Wild and Semi-Wild Edible Fruit Species used by Maale and Ari Ethnic Communities in Southern Ethiopia. Ethnobotany Research and Applications. 12:455471.

Kim H, Song MJ. 2008. Ethnobotany. Worldscience Co. Seoul, Korea.

Kim H, Song MJ, Potter D. 2006. Medicinal efficacy of plants utilized as temple food in traditional Korean Buddhism. Journal of Ethnopharmacology. 104(1):32-46.

Trotter RT, Logan MH. 1986. Informant Consensus: a new approach for identifying potentially effective medicinal plants. Plants in Indigenous Medicine \& Diet: Biobehavioral Approaches. Redgrave Publishing Company, Bedford Hills, NY.

Mahmood A, Qureshi RA, Mahmood A, Sangi Y, Shaheen H, Ahmad I, Nawaz Z. 2011a. Ethnobotanical survey of common medicinal plants used by people of district Mirpur, AJK, Pakistan. Journal of Medicinal Plant Research. 5(18):44934498.

Mahmood A, Riffat NM, Zabta KS, Aqeel M. 2011b. Ethnobotanical survey of plants from Neelum, Azad Jammu and Kashmir, Pakistan. Pakistan Journal of Botany. 43(105):10.

Mahmood T, Khan MA, Ahmad J, Ahmad M. 2004. Ethnomedicinal studies of kala chitta hills of district Attock, Pakistan. Asian Journal of Plant Sciences. 3(3):335-339.

Manandhar NP. 2002. Ethnomedicinal plants diversity and their conservation in Nepal. Recent Progress in Medicinal Plants. (Eds.) Singh V.K., J.N. Govil and G. Singh. Publ. Stadium Press LLC, USA, 1:41-46.

Martín RS, Briones R. 1999. Industrial uses and sustainable supply of Quillaja saponaria (Rosaceae) saponins. Economic Botany. 53(3):302-311.

Marwat SK, Khan MA, Khan MA, Ahmad M, Zafar M, Rehman F, Sultana S. 2009. Fruit plant species mentioned in the Holy Qura'n and Ahadith and their ethnomedicinal importance. American-Eurasian Journal of Agriculture and Environmental Science. 5(2):284-295.

McMichael AJ. 2006. Population health as a primary criterion of sustainability. Eco Health. 3(3):182-186.

Megersa M, Asfaw Z, Kelbessa E, Beyene A, Woldeab B. 2013. An ethnobotanical study of medicinal plants in Wayu Tuka district, east Welega zone of Oromia regional state, West Ethiopia. Journal of Ethnobiology and Ethnomedicine. 9(1):68.
Mesfin A, Giday M, Animut A, Teklehaymanot T. 2012. Ethnobotanical study of antimalarial plants in Shinile District, Somali Region, Ethiopia, and in vivo evaluation of selected ones against Plasmodium berghei. Journal of Ethnopharmacology. 139(1):221227.

Molares S, Ladio A. 2009. Chemosensory perception and medicinal plants for digestive ailments in a Mapuche community in NW Patagonia, Argentina. Journal of Ethnopharmacology. 123(3):397-406.

Muhammad IC, Khan MA. 2008. An ethnomedicinal inventory of plants used for family planning and sex diseases in Samahni valley, Pakistan. Indian Journal of Traditional Knowledge. 7:277-283.

Noor A, Khatoon, S, Ahmed M, Razaq A. 2014. Ethnobotanical study on some useful shrubs of Astore valley, Gilgit-Baltistan, Pakistan. Bangladesh Journal of Botany. 43(1):19-25.

Phillips O, Gentry AH, Reynel C, Wilkin P, GalvezDurand B. 1994. Quantitative ethnobotany and Amazonian conservation. Conservation Biology. 8(1):225-248.

Qureshi R, Waheed A, Arshad M, Umbreen T. 2009. Medico-ethnobotanical inventory of tehsil Chakwal, Pakistan. Pakistan Journal of Botany. 41(2):529-538.

Rahman IU, ljaz F, Afzal A, Iqbal Z, Ali N, Khan SM. 2016. Contributions to the phytotherapies of digestive disorders: Traditional knowledge and cultural drivers of Manoor Valley, Northern Pakistan. Journal of Ethnopharmacology. 192:30-52.

Rokaya MB, Münzbergová Z, Timsina B. 2010. Ethnobotanical study of medicinal plants from the Humla district of western Nepal. Journal of Ethnopharmacology. 130(3):485-504.

Rokaya MB, Uprety Y, Poudel RC, Timsina B, Münzbergová Z, Asselin H, Tiwari A, Shrestha SS, Sigdel SR. 2014. Traditional uses of medicinal plants in gastrointestinal disorders in Nepal. Journal of Ethnopharmacology. 158:221-229.

Sarma, H, Deka S, Deka H, Saikia RR. 2012. Accumulation of heavy metals in selected medicinal plants. In Reviews of environmental contamination and toxicology. Springer, New York, NY. pp. 63-86.

Saikia AP, Ryakala VK, Sharma P, Goswami P, Bora U. 2006. Ethnobotany of medicinal plants used by Assamese people for various skin ailments and cosmetics. Journal of Ethnopharmacology. 106(2):149-157.

Shad AA, Shah HU, Bakht J. 2013. Ethnobotanical assessment and nutritive potential of wild food plants. Journal of Animal and Plant Sciences. 23(1):92-97. 
Shah A, Rahim S. 2017. Ethnomedicinal uses of plants for the treatment of malaria in Soon Valley, Khushab, Pakistan. Journal of Ethnopharmacology. 200:84-106.

Shah GM, Khan MA. 2006. Checklist of Medicinal Plants of Siran Valley, Mansehra, Pakistan. Ethnobotany Leaflets. 1:6.

Shah SA, Shah NA, Ullah S, Alam MM, Badshah H, Ullah S, Mumtaz AS. 2016. Documenting the indigenous knowledge on medicinal flora from communities residing near Swat River (Suvastu) and in high mountainous areas in Swat-Pakistan. Journal of Ethnopharmacology. 182:67-79.

Sher H, Bussmann RW, Hart R, de Boer HJ. 2016. Traditional use of medicinal plants among Kalasha, Ismaeli and Sunni groups in Chitral District, Khyber Pakhtunkhwa province, Pakistan. Journal of Ethnopharmacology. 188:57-69.

Sher Z, Khan Z, Hussain F. 2011. Ethnobotanical studies of some plants of Chagharzai valley, district Buner, Pakistan. Pakistan Journal of Botany. 43(3):1445-1452.

Shinwari MI, Khan MA. 2000. Folk use of medicinal herbs of Margalla hills national park, Islamabad. Journal of Ethnopharmacology. 69(1):45-56.

Shinwari ZK, Gilani SS. 2003. Sustainable harvest of medicinal plants at Bulashbar Nullah, Astore (northern Pakistan). Journal of Ethnopharmacology. 84(2):289-298.

Street RA, Prinsloo G. 2013. Commercially important medicinal plants of South Africa: a review. Journal of Chemistry. 1-16. doi:10.1155/2013/205048.

Tabuti JRS, Dhillion SS, Lye KA. 2004. The status of wild food plants in Bulamogi County, Uganda. International Journal of Food Sciences and Nutrition. 55(6):485-498.

Tareen NM, Saeed UR, Shinwari ZK, Bibi T. 2016. Ethnomedicinal utilization of wild edible vegetables in district Harnai of Balochistan province, Pakistan. Pakistan Journal of Botany. 48(3):1159-1171.

Tariq A, Mussarat S, Adnan M, Abd-Allah EF, Hashem A, Alqarawi AA, Ullah R. 2015. Ethnomedicinal evaluation of medicinal plants used against gastrointestinal complaints. Biomed Research International. 2015: 1-14. Article ID 892947.

Haq UI, Hussain M. 1993. Medicinal plants of Mansehra. Hamdard Medicine Journal. 36(3):63100.

Ullah M, Khan MU, Mahmood A, Malik RN, Hussain M, Wazir SM, Daud M, Shinwari ZK. 2013. An ethnobotanical survey of indigenous medicinal plants in Wana district South Waziristan agency,
Pakistan. Journal of Ethnopharmacology. 150(3):918-924.

Uniyal SK, Singh KN, Jamwal P, Lal B. 2006. Traditional use of medicinal plants among the tribal communities of Chhota Bhangal, Western Himalaya. Journal of Ethnobiology and Ethnomedicine. 2(1):14.

Upadhyay B, Singh KP, Kumar A, 2010. Pharmacognostical and antibacterial studies of different extracts of Euphorbia hirta L. Journal of Phytology. 2(6): 55-60.

WHO. 2014. World Health Statistics. WHO Press, Switzerland, 2014.

Zheng XL, Xing FW. 2009. Ethnobotanical study on medicinal plants around Mt. Yinggeling, Hainan Island, China. Journal of Ethnopharmacology. 124(2):197-210. 